\title{
Precipitation climatology over Mediterranean Basin from ten years of TRMM measurements
}

\author{
A. V. Mehta ${ }^{1}$ and S. Yang ${ }^{2}$ \\ ${ }^{1}$ Joint Center for Earth Systems Technology, University of Maryland Baltimore County, Baltimore, MD 21228, USA \\ ${ }^{2}$ I. M. Systems Group and Center for Satellite Applications and Research (STAR)/NESDIS/ NOAA, Camp Springs, \\ MD 20746, USA
}

Received: 16 January 2008 - Revised: 17 June 2008 - Accepted: 30 June 2008 - Published: 22 December 2008

\begin{abstract}
Climatological features of mesoscale rain activities over the Mediterranean region between $5^{\circ} \mathrm{W}-40^{\circ} \mathrm{E}$ and $28^{\circ} \mathrm{N}-48^{\circ} \mathrm{N}$ are examined using the Tropical Rainfall Measuring Mission (TRMM) 3B42 and 2A25 rain products. The $3 \mathrm{~B} 42$ rainrates at 3 -hourly, $0.25^{\circ} \times 0.25^{\circ}$ spatial resolution for the last 10 years (January 1998 to July 2007) are used to form and analyze the 5-day mean and monthly mean climatology of rainfall. Results show considerable regional and seasonal differences of rainfall over the Mediterranean Region. The maximum rainfall $\left(3-5 \mathrm{~mm} \mathrm{day}^{-1}\right)$ occurs over the mountain regions of Europe, while the minimum rainfall is observed over North Africa $\left(\sim 0.5 \mathrm{~mm} \mathrm{day}^{-1}\right)$. The main rainy season over the Mediterranean Sea extends from October to March, with maximum rainfall occurring during November-December. Over the Mediterranean Sea, an average rainrate of $\sim 1-2 \mathrm{~mm} \mathrm{day}^{-1}$ is observed, but during the rainy season there is $20 \%$ larger rainfall over the western Mediterranean Sea than that over the eastern Mediterranean Sea. During the rainy season, mesoscale rain systems generally propagate from west to east and from north to south over the Mediterranean region, likely to be associated with Mediterranean cyclonic disturbances resulting from interactions among large-scale circulation, orography, and land-sea temperature contrast.
\end{abstract}

\section{Introduction}

The Mediterranean Region (MR), including the Mediterranean Sea, southwestern and south-central Europe, North Africa, and Middle East, has complex orograhical and landsea coastal features. Because of these special geographical features, the climate in the MR, generally considered to have

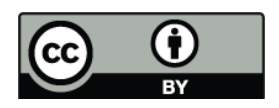

Correspondence to: A. V. Mehta (amita@radar.gsfc.nasa.gov) mild/wet winters and dry/hot summers, actually exhibits intricate spatial and temporal characteristics (Lionello et al., 2006a). Past studies have shown that while MR is located in the sub-tropical zone, its climate is influenced by both tropical and mid-latitude climate systems. Particularly, MR precipitation is shown to be influenced by North Atlantic Oscillation pattern, eastern Atlantic, western Russian, and Scandinavian patterns (Trigo et al., 2006), and El Nino Southern Oscillation (ENSO), Asian and African monsoons, Atlantic hurricanes, and Saharan dust (Alpert et al., 2006).

Seasonal variation of MR rainfall is found to be mostly associated with synoptic and mesoscale cyclonic disturbances occurring on 2-8 days time scale (Lionello et al., 2006b). The development and passage of these rain systems over MR appear to be affected by a combination of factors such as large-scale circulation, local orographical features, and landsea temperature contrast. Numerous published studies have used sea level pressure, geopotential heights, winds and other parameters from either National Center for Environmental Prediction (NCEP) or European Center for Medium Range Forecasting (ECMWF) model analyses to detect and document cyclonic disturbances over MR (e.g. Homar et al., 2007; Trigo 2006). Rainfall analysis over MR is limited to measurements available from coastal rain gauge stations around the Mediterranean Sea (Xoplaki et al., 2004). Large areas of the Mediterranean Sea are void of direct measurements. To understand impacts of climate variability and change on the MR rainfall extremes, it is critical to observe and model these mesoscale rain disturbances.

The key objective of this study is to provide an improved description of the climatological features of MR precipitation using the most accurate rain measurements to date from the Tropical Rainfall Measuring Mission (TRMM) (e.g., Kummerow et al., 2001; Yang and Smith, 2008). As described in Sect. 2, high quality TRMM rain products with higher spatial and temporal resolutions are available over MR. Results and summary are given in Sects. 3 and 4, respectively.

Published by Copernicus Publications on behalf of the European Geosciences Union. 


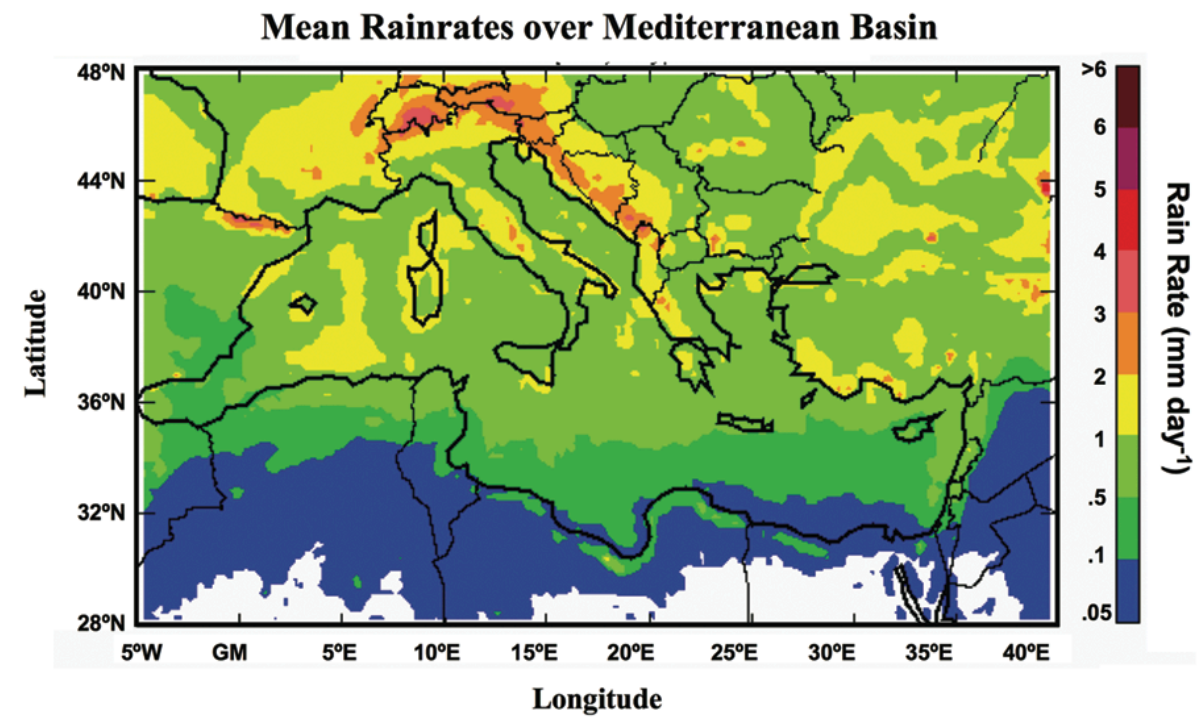

Fig. 1. Mean rainrates over Mediterranean Basin from January 1998-July 2007 TRMM measurements.
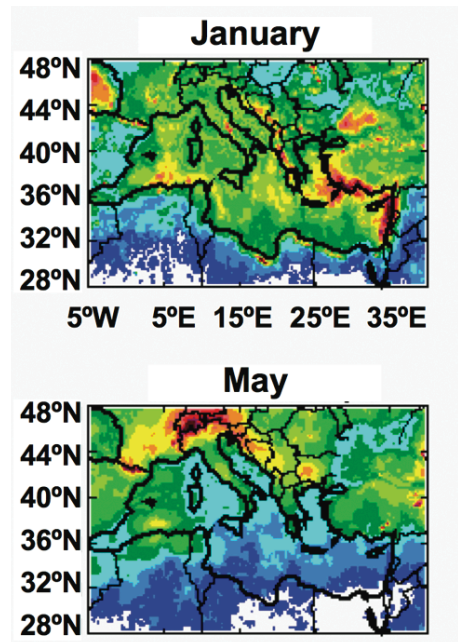

$5^{\circ} \mathrm{W} \quad 5^{\circ} \mathrm{E} \quad 5^{\circ} \mathrm{E} 25^{\circ} \mathrm{E} 35^{\circ} \mathrm{E}$

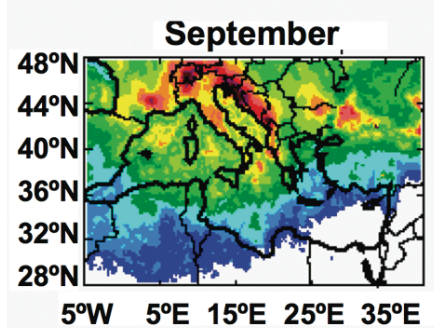

$5^{\circ} \mathrm{W} \quad 5^{\circ} \mathrm{E} 15^{\circ} \mathrm{E} 25^{\circ} \mathrm{E} \quad 35^{\circ} \mathrm{E}$
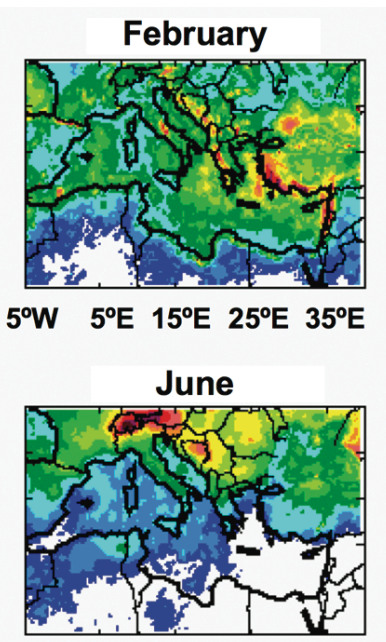

$5^{\circ} \mathrm{W} \quad 5^{\circ} \mathrm{E} \quad 15^{\circ} \mathrm{E} \quad 2^{\circ} \mathrm{E} \quad 35^{\circ} \mathrm{E}$

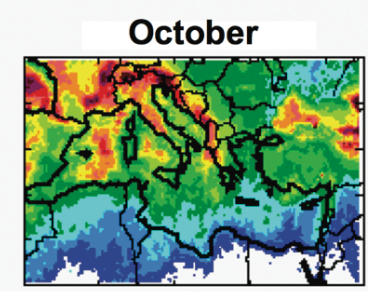

$5^{\circ} \mathrm{W} \quad 5^{\circ} \mathrm{E} \quad 15^{\circ} \mathrm{E} 25^{\circ} \mathrm{E} 35^{\circ} \mathrm{E}$

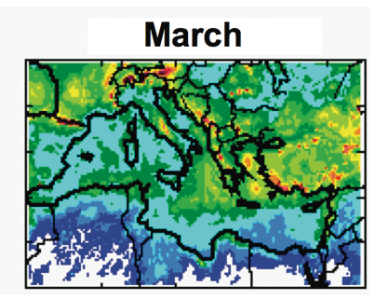

$5^{\circ} \mathrm{W} \quad 5^{\circ} \mathrm{E} \quad 1^{\circ} \mathrm{E} 25^{\circ} \mathrm{E} 35^{\circ} \mathrm{E}$

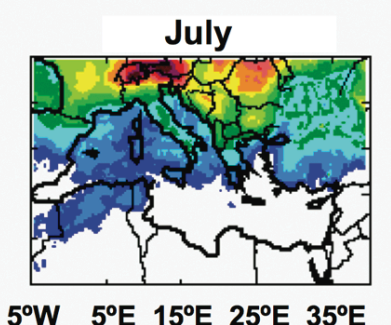

列

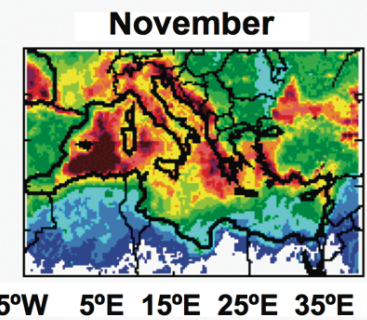

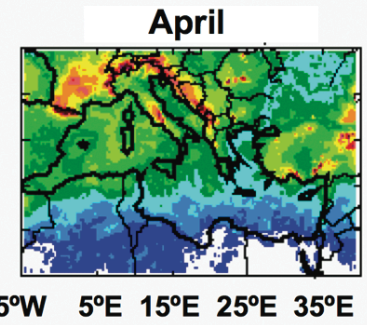

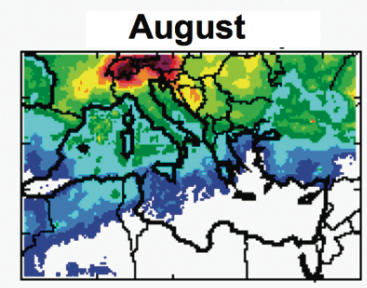

$5^{\circ} \mathrm{W} 5^{\circ} \mathrm{E} 15^{\circ} \mathrm{E} 25^{\circ} \mathrm{E} 35^{\circ} \mathrm{E}$

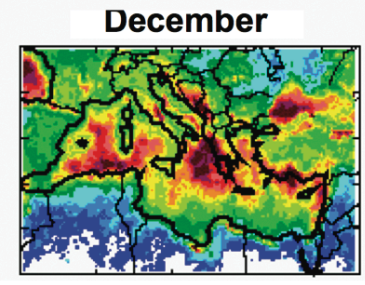

$5^{\circ} \mathrm{W} \quad 5^{\circ} \mathrm{E} 15^{\circ} \mathrm{E} 25^{\circ} \mathrm{E} 35^{\circ} \mathrm{E}$

Rain Rate (mm day $\left.{ }^{-1}\right)$

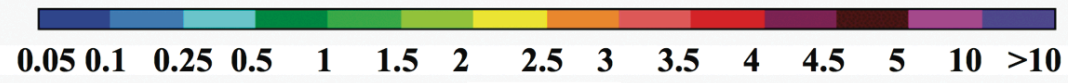

Fig. 2. Spatial distribution of mean monthly rainrates for annual cycle over Mediterranean Basin from January $1998-J u l y ~ 2007$. 


\section{Data and analysis}

TRMM, carrying the first space precipitation radar (PR) and a Microwave Imager (TMI), was launched in November 1997, and has provided 10 years of reliable rainfall data record useful for climate studies of precipitation. Several rain products from TRMM have been developed with PR, TMI, and combined PR/TMI measurements (Kummerow et al., 2001). Moreover, a blended TRMM rain product (3B42), based on TRMM calibrated multiple satellite microwave and infrared measurements, provides a global coverage of precipitation over $50^{\circ} \mathrm{S}-50^{\circ} \mathrm{N}$ latitude belt at $0.25^{\circ} \times 0.25^{\circ}$ spatial and 3-hourly temporal resolutions (Huffman et al., 2007). The 3B 42 datasets consist of $45 \%$ precipitation from passive microwave radiometers (i.e., TRMM-TMI, AQUA-AMSR, and DMSP-SSMIs), 40\% from operational microwave sounding frequencies (i.e., NOAA-AMSUs), and $15 \%$ infrared measurements from geostationary satellites (i.e., GOES, METEOSAT/MSG). 3B42 rain products are based on first using the PR/TMI combined rainrates to calibrate rain estimates from other microwave and IR measurements, then adjusting their rainrates with the surface rain gauge measurements at monthly time scales. While all rain retrieval products have uncertainties, 3B42 product is better suitable for the present study because the available rain gauge measurements are also used in the calibration process. The detailed 3B42 product description can be found at http://trmm.gsfc.nasa.gov.

TRMM 3B42 rain products from January 1998 to July 2007 are first used to form 5-day mean and then monthly mean rainrate values over the selected $\mathrm{MR}\left(5^{\circ} \mathrm{W}-40^{\circ} \mathrm{E}\right.$ and $\left.28^{\circ} \mathrm{N}-48^{\circ} \mathrm{N}\right)$. Similar TRMM PR rain products (2A25) are also utilized. The 10-year mean climatology is examined to study spatial/seasonal distributions of rain over MR. Preliminary results of this analysis are presented in the following section.

\section{Climatological rain over the Mediterranean Region}

Figure 1 shows 10-year mean rainrates over Mediterranean Region from January 1998-July 2007. It is evident that rainrates over the Mediterranean Sea and surrounding continental regions vary from 0.1 to $5 \mathrm{~mm} \mathrm{day}^{-1}$. The rain distribution is closely tied to the orography of the continental regions. The rain maximum of $2-5 \mathrm{~mm} \mathrm{day}^{-1}$ is found over the Alps, extending along the Dinaric Alps in Eastern Europe. The localized rain maxima are also situated over the Apennines and Pyrenees in western Europe, and over the Pindus, Rhodope, Carpathian, and Taurus mountains in eastern Europe. While the minimum rainfall is found over northern Africa $\left(\sim 0.1 \mathrm{~mm} \mathrm{day}^{-1}\right)$, relatively larger rainrates over the Atlas Mountains are evident $\left(0.5-1 \mathrm{~mm} \mathrm{day}^{-1}\right)$. Although rainrates over most of the Mediterranean Sea remain

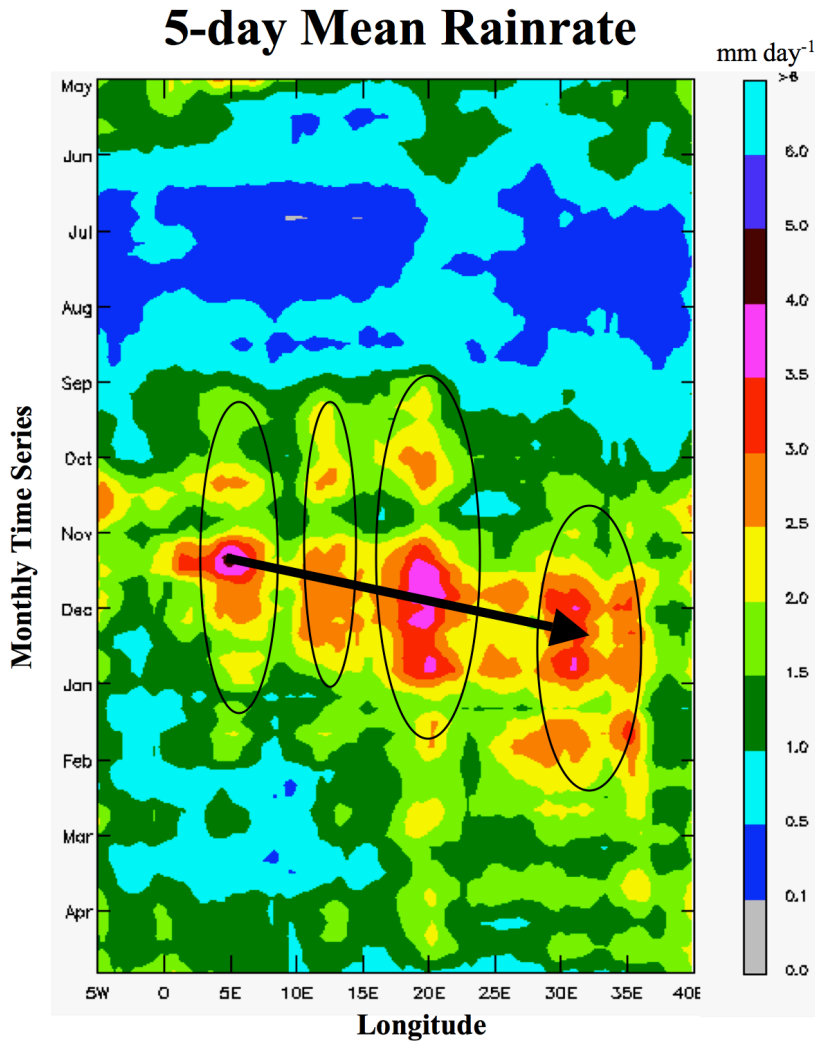

Fig. 3. The time-longitude section of mean monthly rainfall between $32^{\circ} \mathrm{N}$ and $44^{\circ} \mathrm{N}$ over the Mediterranean region from January 1998-July 2007. The overlapped arrow shows the general eastward rainfall propagation over the Mediterranean Basin.

$\sim 1 \mathrm{~mm} \mathrm{day}^{-1}$ or less, a maxima $\left(\sim 2 \mathrm{~mm} \mathrm{day}^{-1}\right)$ confined over the western Mediterranean is obvious.

Figure 2 shows the monthly variations of the 10 -year mean MR rain climatology. During January-August, the continental rainfall builds up $\left(2-5 \mathrm{~mm} \mathrm{day}^{-1}\right)$ while rainfall over the Mediterranean Sea remains lower. In the early part of year, more rainfall occurs over eastern Europe and western Turkey, while from May onwards larger rainfall occurs over western and central Europe, extending up to Ukraine. Over the Mediterranean Sea, the main raining season is from October to March, which is consistent with the study by Xoplaki et al. (2004). A dramatic increase of rainfall is noted over western Mediterranean Sea in November and over central and eastern Mediterranean in December (3-5 mm day ${ }^{-1}$ ). The averaged rainrate over the western Mediterranean Sea (west of $16^{\circ} \mathrm{E}$ ) is $\sim 20 \%$ larger than that over the eastern Mediterranean Sea during the raining season. The seasonal rainfall evolution over north Africa closely follows that over the Mediterranean Sea with a much smaller magnitude $\left(\sim 0.5 \mathrm{~mm} \mathrm{day}^{-1}\right)$.

Figure 3 shows the longitude-time distribution of rainrates averaged between $32^{\circ} \mathrm{N}-44^{\circ} \mathrm{N}$ over MR, presenting the 


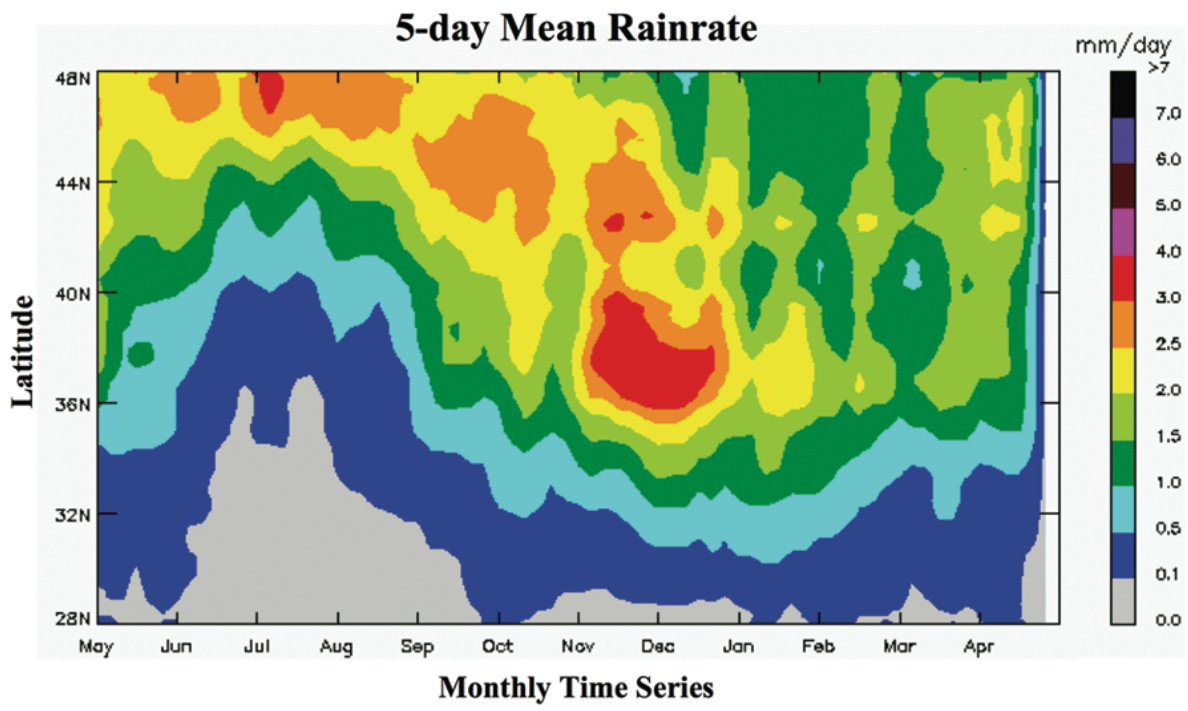

Fig. 4. The time-latitude section of mean monthly rainfall between $5^{\circ} \mathrm{W}$ to $35^{\circ} \mathrm{E}$ over the Mediterranean region from January $1998-\mathrm{July}$ 2007.

overall characteristics of MR rain systems. The most intense rainfall activity centers are found in western Mediterranean $\left(5^{\circ} \mathrm{E}\right)$, Gulf of Genoa and southern Italy $\left(10-12^{\circ} \mathrm{E}\right)$, Eastern Europe and Agean Sea $\left(20-22^{\circ} \mathrm{E}\right)$, Cyprus and Black Sea $\left(30^{\circ} \mathrm{E}\right)$. These areas are known for active cyclone activities (Lionello et al., 2006b). The most interesting feature observed in Fig. 3 is that that rain activity starts in October in the western MR, and then extends eastward up to $35^{\circ} \mathrm{E}$ between November and January. The rain activity subsides over the western MR after January, but persists until March in the eastern MR. Similar features are also found in TRMM $\mathrm{PR}$ rain product (not shown).

Figure 4 shows the time-latitude distribution of rainrates averaged between $5^{\circ} \mathrm{W}$ to $35^{\circ} \mathrm{E}$. The MR rain systems propagate from north to south during October to January while a weak south to north propagation is evident during March to July. The north to south propagation of rain systems during the winter season suggest their origin in mid-latitudes. The south to north propagation of rain systems during spring and summer may be related to the tropical cyclonic disturbances. Particularly, the disturbances arriving from north Africa are known to intensify by the Atlas mountain slope as they enter MR. As reviewed by Lionello et al. (2006b), MR is a region where frequent cyclonic disturbances occur, resulting from complex interactions involving atmospheric dynamics, orography, and land-sea temperature gradients. Detailed analysis of these factors is required to understand the propagation features noted in Figs. 3 and 4.

\section{Summary}

The climatological features of mesoscale rain activities over the Mediterranean Region $\left(5^{\circ} \mathrm{W}-35^{\circ} \mathrm{E}\right.$ and $\left.32^{\circ} \mathrm{N}-48^{\circ} \mathrm{N}\right)$ are examined using the TRMM $3 \mathrm{~B} 42$ and $2 \mathrm{~A} 25$ rain products. Results show substantial regional differences of MR rainfall. The maximum rainfall $\left(3-5 \mathrm{~mm} \mathrm{day}^{-1}\right)$ occurs over the mountain regions of Europe, while the minimum rainfall is over north Africa $\left(\sim 0.5 \mathrm{~mm} \mathrm{day}^{-1}\right)$. Over the Mediterranean Sea, an average rainrate of $\sim 1-2 \mathrm{~mm} \mathrm{day}^{-1}$ is observed with a maximum rainrate found over the western Mediterranean Sea. The main rainy season over the Mediterranean Sea extends from October to March, but maximum rainfall occurs during November-December. There are preferred areas of intensified rain activities over MR. Rain systems first emerge in the western MR, and then extend eastward up to Middle East. In addition, a southward (northward) propagation of rain systems is also clearly seen during the winter (spring-summer) season. These features indicate that the MR precipitation is strongly associated with the mesoscale disturbances originating from both mid-latitudes and tropics. A detailed investigation is under way to better understand these MR rain systems, their inter-annual variability, and mechanisms.

Acknowledgements. We are grateful to Eric Smith for his suggestions, advice, and support for this work. We thank Ms. Karen Mitchell for editing the manuscript. The rain datasets were supplied by the TRMM Science Data and Information System (TSDIS). This work was supported by the NASA Precipitation Measurement Mission (PMM) Science Team research program.

Edited by: A. Mugnai

Reviewed by: one anonymous referee 


\section{References}

Alpert, P., Baldi, M., Ilani, R., et al.: Relations between climate variability in the Mediterranean region and the tropics: ENSO, South Asian and African monsoons, hurricanes and Saharan dust, Mediterranean Climate Variability, Elsevier B. V., 149-177, 2006.

Homar, V., Jansa, A., Campins, J., Genoves, A., and Ramis. C.: Towards a systematic climatology of sensitivities of Mediterranean high impact weather: a contribution based on intense cyclones, Nat. Hazards Earth Syst. Sci., 7, 445-454, 2007, http://www.nat-hazards-earth-syst-sci.net/7/445/2007/.

Huffman, G. J., Adler, R. F., Bolvin, D. T., Gu, G., Nelkin, E. J., Bowman, K. P., Hong, Y., Stocker, E. F., and Wolff, D. B.: The TRMM Multi-satellite Precipitation Analysis (TMPA): quasiglobal, multi-year, combined-sensor precipitation estimates at fine scales, J. Hydrometeorol., 8(1), 38-55, 2007.

Kummerow, C., Hong, Y., Olson, W. S., Yang, S., Adler, R. F., Mccollum, J., Ferraro, R., Petty, G., and Wilheit, T. T.: The evolution of the Goddard Profiling Algorithm (GPROF) for rainfall estimation from passive microwave sensors, J. Appl. Meteorol., 40, 1801-1820, 2001.
Lionello, P., Malanotte-Rizzoli, P., Boscolo, R., et al. : The Mediterranean Climate: An overview of the main characteristics and issues, Mediterranean Climate Variability, Elsevier B. V., 1-26, $2006 a$.

Lionello, P., Bhend, J., Buzzi, A., et al. : Cyclones in the Mediterranean region: climatology and effects on the environment, Mediterranean Climate Variability, Elsevier B. V., 325-372, 2006 b.

Trigo, R. M., Xoplaki, E., Zorita, E., et al.: Relationship between variability in the Mediterranean region and mid-latitude variability, Mediterranean Climate Variability, Elsevier B. V., 179-226, 2006.

Trigo, I. F.: Climatology and interannual variability of storm-tracks in the Euro-Atlantic sector: a comparison between ERA-40 and NCEP/NCAR reanalysis, Clim. Dynam., 26, 127-143, 2006.

Xoplaki, E., Gonzalez-Rouco, J. F., Luterbacher, J., and Wanner, H.: Wet season Mediterranean precipitation variability: influence of large-scale dynamics and trends, Clim. Dynam., 23, 63-78, 2004.

Yang, S. and Smith, E. A.: Convective - stratiform precipitation variability at seasonal scale from eight years of TRMM observations: Implications for multiple modes of diurnal variability, J. Climate, 21, 4087-4114, 2008. 